\title{
Stability, Ambiguity and Change in the Discourses of NATO allies in the Black Sea region: The Cases of Romania, Bulgaria and Turkey
}

Valentin Naumescu

\section{Abstract}

Shortly after the Crimea crisis of March 2014, NATO started a process of strategic reflection and a series of actions under the umbrella of the 'Pivot to East'. On the South of its Eastern flank, the Black Sea region looms as one of the most unstable areas, with a number of frozen conflicts in non-NATO countries as well as an increasing unrest overall. This article explores the political discourses, commitments and attitudes towards NATO of the three allies at the Black Sea, namely Romania, Bulgaria and Turkey, as well as exploring their role in regional security. The purpose of the research is to compare NATO's representation in the mainstream politics of these countries. Based on discourse analysis and the comparative method, the paper examines to what extent stability, ambiguity and change are present in the Southeast allies' discourses on NATO.

\section{KEY WORDS:}

NATO, political discourse, Black Sea region, Romania, Bulgaria, Turkey 
The Black Sea region was, for a long time, a confusing and heterogeneous area of mixed cultures, influences and interests. At the periphery of all ancient and modern empires from the West, North-East or South, the basin of the Black Sea represented for centuries a meeting place, but also a fault line for various civilisations, religions, ethnicities, nations and minorities. It is already commonplace to say that the Black Sea works as a crossroads for the main West-East and North-South strategic corridors connecting the European peninsula with the Eurasian bloc, as well as with the Middle East. Neal Ascherson even names the region "the birthplace of civilisation and barbarism" but, coming to recent tensions between Russia and the West, he also observes that "because of this rivalry, the Black Sea is no longer considered 'peripheral' by European and American leaders. Increasingly, the region is 'courted' by conferences, 'action plans' and "neighbourhood policies'" (Ascherson 2007: xii).

The role of this geopolitical pivot is somehow valid even today. Articulating the eastern neighbourhood with the southern neighbourhood of the western world, represented mainly by the North Atlantic Alliance and the European Union, the Black Sea region keeps its strategic significance in contemporary international politics. The shocking annexation of Crimea in March 2014 brought back into international attention the strategic and geopolitical value of this once considered peripheral region.

In the narrow sense of having Black Sea coasts, only six countries can be considered as part of the region: Turkey, Bulgaria, Romania, Ukraine, Russia and Georgia. Nevertheless, the Organization of the Black Sea Economic Cooperation (BSEC), established in 1992 in Istanbul, has 12 member states: the six already mentioned plus Albania, Armenia, Azerbaijan, Greece, the Republic of Moldova and Serbia. Wondering if the Black Sea region, in its narrow or broad conceptualization, is really a coherent region, Charles King remarks that it is extremely difficult to identify a common Black Sea regional identity, as "political trajectories and political realities across the wider south-eastern Europe are varied: democratic and authoritarian, reformist and reactionary, real states and imagined ones" (King 2004: 8). 
The Black Sea is surrounded today by a 'belt' of frozen conflicts and instability, on the North, East and South. Looking at Crimea, East of Ukraine, Russia, Georgia and its separatist regions, the South Caucasus, and even a turbulent and confused Turkey, we understand how much potential for conflict and instability there is in the region. On the western shore, Romania and Bulgaria are both EU and NATO member states, the presumption being that simultaneous membership to these two essential political, economic and military structures of the Western order is an indication for more predictability and stability in national politics. However, the election of the new Bulgarian president in November 2016, the socialist retired general Rumen Radev, considered by local and European mass-media an ambiguous if not a real 'pro-Russian leader' (Euronews 2016), places Bulgaria in a new and rather unclear light.

Although united by a pro-West strategic option, the three NATO member states in the Black Sea region have different political and cultural backgrounds. Turkey, the only Muslim-majority country in the Euro-Atlantic system, with a strong Kemalist and secular orientation in government until recently, joined the Alliance in 1952, together with Greece, in light of the Truman Doctrine concerned mainly on the strategic need to avoid an imminent confrontation between the two rival, neighbouring, non-communist states. The failed coup attempt in the summer of 2016 prompted a period of uncertainty in Turkey-US bilateral relations as well as Turkey's NATO commitment (Emmott 2016).

Romania and Bulgaria, both post-communist democracies, joined NATO in 2004 with the second wave of eastern enlargement after the Cold War. Traditionally, Bulgaria has had more substantial relations and sympathy for Russia due to its Slavic cultural roots, and this is still valid today. In Romania, maybe more than everywhere else in the Southeast Europe and the Black Sea region, a political, elitist and popular Russophobic feeling is present (Tsygankov 2009) that was evident even before 1989. This feeling manifested as a deep anti-Soviet attitude, making Bucharest one of the most fervent Antlanticist/pro-NATO/pro-US capitals on the European continent in the past two decades.

Based on a comparative qualitative research method, specifically discourse theory, this article examines the political discourses on NATO 
of the three allies with Black Sea coasts: Romania, Bulgaria and Turkey. High-ranking officials but also significant opposition leaders will be taken into consideration. The research question is whether recent international developments with the ascension of nationalist and populist parties, the crisis of the European Union, the failed coup attempt in Turkey or the weakening of transatlantic relations have prompted changes in these states' orientation and perspectives with regard to NATO. Political elites are taken into consideration, both from the government and opposition side, in order to foreshadow possible developments in the coming years and explore NATO perspectives in the region.

The article is structured in five sections. After the introduction and the theoretical framework, the analysis approaches the Black Sea NATO allies into two distinct sections/categories: Romania and Bulgaria are treated together as EU member states, then Turkey, a non-EU country with a Muslim majority, having a vast part of its territory on the Asian continent and massive connections with the Middle East. The last section contains the conclusions.

\section{Conceptual framework, strategic approaches and doctrines of security in the Black Sea region}

Being a region of confluence with very different historic, political and cultural traditions, the basin of the Black Sea used to bring together Western oriented and Eastern oriented regimes. Russia and Turkey were always the two most important powers at the Black Sea, so it was essential for the United States to get a strategic ally in the region during the Cold War. That steady ally was, for almost a half-century, Turkey.

Robert Kaplan connects the second NATO extension to the East with the Kosovo war. In 1999 Romania allowed American bombers to use its airspace in order to strike at the targets of the Milosevich regime and that political attitude of Bucharest gave strategic value to the entire subregion of Southeast Europe: "the war of Kosovo in 1999, like the attacks 
of $9 / 11$, legitimated the subsequent extension of the NATO area as far as the Black Sea" (Kaplan 2014: 55). Even after the second wave of the Alliance's eastern enlargement, diversity remained the most relevant characteristic of the region in terms of security approaches. In 2004, Romania and Bulgaria raised to three, the number of the NATO allies having Black Sea coasts, and consolidated the south of the so-called Eastern Flank of the Atlantic Alliance. Georgia behaved politically as a pro-West country and so did Ukraine in its foreign policy, the latter with on and off periods during the tenure of presidents Yushchenko, Yanukovych and Poroshenko. Nevertheless, a NATO accession invitation for the two post-Soviet republics, proposed by the United States at the Bucharest NATO Summit of April 2008, was refused by the western European powers (Erlanger and Lee Meyers 2008).

The region was and still is also relevant for US security strategy, being part and parcel of the peripheral 'belt' of the former Soviet Union. In his famous People, States and Fear, Barry Buzan explained that the US-European founded a 'win-win game' with NATO, and indirectly predicted the deployment of the American anti-missile shield in Romania, 25 years later:

"In Europe, the NATO structure symbolized the inability of individual states to defend themselves. But American involvement all along the periphery of the Soviet sphere merely staked out the boundaries for the forward defence of the United States" (Buzan 1991: 283).

Various definitions of security give an image of what interests the Black Sea states may have in joining NATO. Some of these conceptualizations see the issue of national security in its basic, realist perspectives: "national security may be defined as the ability to withstand aggression from aboard" (Luciani 1989: 151). Other approaches speak about national values and adversities:

"national security is that part of government policy having as its object the creation of national and international political conditions favourable to the protection or extension of vital national values against existing and potential adversaries" (Trager and Simonie 1973: 36). 
The most comprehensive definitions take into consideration both external and internal threats:

"national security is the preservation of a way of life acceptable to the ... people and compatible with the needs and legitimate aspirations of others. It includes freedom from military attack or coercion, freedom from internal subversion and freedom from the erosion of the political, economic and social values which are essential to quality of life" (National Defence College of Canada 1989).

What do all of these conceptual clarifications mean for the new Black Sea allies? It simply gives a strong indication of the way in which most of the post-communist countries in the region projected their national security, starting in the 1990s. The North-Atlantic Alliance was largely perceived in the new democracies as the most credible guarantee for their future security in the post-Cold War order. Only two post-Soviet republics, Ukraine and the Republic of Moldova, opted for the principle of neutrality in their new constitutions, even though the governments in Kyiv and Chişinău usually moved for political and economic integration with the West. Georgia tried hard to get access to NATO but the RussianGeorgian war of August 2008 and the frozen conflict that followed in the separatist regions of South Ossetia and Abkhazia placed Tbilisi on a nonelective position for full membership.

With regard to the Alliance's members in the region, a comparative analysis of the official documents of security policy of the three capitals is useful. Romania adopted from the first moment of its membership a very 'orthodox' doctrine of security in relation to NATO. A full commitment looms in the five point goals of Romania as a NATO member:

1. "A robust and relevant alliance based on a solid transatlantic partnership capable to respond effectively to new security threats. A robust and dynamic transatlantic partnership is a crucial factor in addressing new security risks facing the transatlantic community.

2. Fulfilling the commitments as a NATO member regarding the participation in NATO operations and missions. 
3. Supporting NATO's role in providing stability, as a promoter of reforms and regional cooperation in the immediate vicinity of Romania (Balkans and the Black Sea area).

4. Development of partnerships between NATO-EU and NATO-UN.

5. Supporting the transformation process of NATO" (Ministry of Foreign Affairs of Romania 2017).

An almost similar perspective is apparent in Bulgaria's official security doctrine. The same implication and engagement to NATO values and policies is assumed in Sofia, with a specific mention related to the development of cooperation between NATO and Russia. This cooperation involves political dialogue and practical cooperation, somehow surprising given the well-known context of frozen relations between the North Atlantic Alliance and the Russian Federation:

"Bulgaria's accession to NATO was a key priority of the foreign policy of our country in the last decade of the 20th century. [...] Implementation of allied commitments stemming from NATO membership is a core element of the defence policy of our country. NATO remains the key guarantor of security of Bulgaria and renders more effective the successful response to possible threats to the country. In turn, Bulgaria is an active and predictable Member of the Alliance and seeks to contribute its maximum to its successful activities in various spheres. The ongoing process of transformation in the Alliance is essential to NATO's successful adaptation to the changing security environment and the performance of emerging operational tasks. Bulgaria supports the various initiatives aimed at meeting new security challenges and at development of military capabilities, as launched at NATO summits in Prague (2002), Istanbul (2004), Riga (2006) and Lisbon (2010). [...] Bulgaria supports the development of cooperation between NATO and Russia as essential for security in the EuroAtlantic area in two interrelated aspects: that of the political dialogue and that of practical cooperation" (Ministry of Defence of the Republic of Bulgaria 2017).

As former members of the defunct Warsaw Pact with rather medium/ 
small military power, both Romania and Bulgaria developed in the 1990s and 2000s, before and after their accession to NATO, a pro-West policy which was intended to ensure that the United States and NATO umbrella of security will fully cover them in the future.

Turkey has a different experience with NATO and to some extent a different approach, which is reflected in its focus on regional affairs, including Ankara's strategic interests in some NATO neighbourhoods such as the Western Balkans but also an interest in the Mediterranean Dialogue and even enhancing relations with the Gulf countries. It is not a surprise, after the Erdogan-Putin rapprochement of 2016-2017, to find mention in the Turkish doctrine about the need for NATO-Russia cooperation and good relationships:

"Ever since our NATO membership in 1952, the North Atlantic Alliance has played a central role in Turkey's security and contributed to its integration with the Euro-Atlantic community. Turkey, in return, has successfully assumed its responsibilities in defending the common values of the Alliance [...] Turkey also supports NATO's transformation efforts, which are crucial for NATO's success. It is therefore making substantial contributions to the NATO Response Force. A Force Command at high readiness level is established in Istanbul. Within the new NATO command structure, the air command in Izmir will be replaced by a land command. [...] Turkey also strongly supports NATO's partnerships. Turkey also believes that a constructive relationship based on mutual understanding, transparency and cooperation between NATO and Russia is important for Euro-Atlantic peace and stability and that the NATO-Russia Council provides the necessary forum for such a relationship.

Turkey believes that the integration of all Western Balkan countries in Euro-Atlantic structures is the key to lasting peace and stability in the region. Turkey therefore supports the membership of interested countries, in particular Macedonia and Bosnia and Herzegovina in NATO, the irreversible strengthening of security in Kosovo and the normalization of relations between Serbia and Kosovo. 
With the understanding that European security cannot be dissociated from Mediterranean security, Turkey shares the belief that the Mediterranean Dialogue should be strengthened in areas where NATO can bring an added value. Turkey also supports further enhancing the relations with Gulf countries through the Istanbul Cooperation Initiative" (Ministry of Foreign Affairs of the Republic of Turkey 2017).

The official NATO doctrines of the three allies do not differ significantly, as the government statements clearly show. However, there are some differences. Bulgaria and Turkey have included cooperation with Russia as a goal, while Turkey mentions a much broader region of interest, covering the Western Balkans, Mediterranean and the Gulf. Recently, Turkey adopted a different position than the United States, Saudi Arabia and the other Arab countries in the Gulf, by supporting the otherwise isolated Qatar and rejecting the allegations of Doha in financing Islamic terrorism.

In the words of Gustav Schmidt, "NATO is often said to be the child or twin of the Cold War [...but] NATO was something more, which allowed it to survive the end of the East-West conflict: it institutionalized political consultation and cooperation" (Schmidt 2014: 46). The switch of the great powers' focus from the concept of hard power to the concept of soft power after the end of the Cold War, corresponded to a parallel shift of NATO from a military focus to a new political and normative focus. This is a significant change for the Black Sea region and its NATO member states, where two out of the three allies (Romania and Bulgaria) were accepted in the frame of the new democratic and liberal paradigm, while the third member state (Turkey) owes its membership to the old Truman Doctrine and the strategies of the Cold War.

In the post-Cold War era, NATO has faced critical questions and sometimes seemed outdated in relation to new security challenges. The idea that NATO in the 21st century is obsolete and suffering a decline in political support from its member states, is rejected by several authors. According to Sebastian Mayer, "declinists forecasting NATO's demise have been proven wrong. The related crisis rhetoric ('NATO is in its worst crisis ever') with its often vague terminology has somewhat subsided" (Mayer 2014: 316). On the same side of the optimists is Wallace Thies, who claims that NATO "endures" and will stay resilient in spite of "superficial comparisons and exaggerate claims" (Thies 2009: 1-10). 

politics

The two NATO allies in the region, which also obtained EU membership in 2007, represent the most stable part of the Black Sea area. It is not only about being 'younger' than Turkey as member states, with a fresher view on the partnership with the United States, but, because of internal political, cultural and societal characteristics, making them feeling part and parcel of Europe.

Romania and Bulgaria started a much more difficult and slower postcommunist transition in the early 1990s, in comparison with the Central European countries regrouped in the so-called Visegrad format.' Many cleavages and internal disagreements divided these two vulnerable democracies, shaping the turbulent political, economic and social contexts of the first post-communist decade. However pro-West consensus loomed quickly both in parliament and in civil society, and was probably the only issue of real national consensus in the two countries.

In Romania, it is indicative that even the fierce nationalist and extremist Great Romania Party of the 1990s and 2000s (now a non-parliamentarian party), was not against European and Euro-Atlantic integration, and was part of the 'Snagov consensus' in 1995. There was actually no political or civic platform denying the 'spirit of Snagov'. Basically, in the resort of Snagov, not far from Bucharest, under the patronage of the Romanian Academy, the intellectual, political and civic Romanian elites of the mid90s gathered for three months in a forum of strategic debate, concluding that the future of Romania has to be connected with the West and with European integration, including EU and NATO values (Snagov Commission Report 1995).

Ion lliescu, a former moderate communist leader of the 1970s who studied in Moscow in the 1950s, became the first President of Romania, after the Revolution of December 1989. It is therefore surprising to find lliescu adapting so quickly to the new pro-West orientation of the country 
and even supporting Romania's integration into the European Union and NATO. In January 1994, Romania was the first post-communist country to join NATO's Partnership for Peace programme. The next President of Romania, Emil Constantinescu, elected in the autumn of 1996, a representative of the centre-right liberal and West-oriented opposition, continued and pushed hard for both of these fundamental objectives of Romania: membership to the North Atlantic Alliance and membership of the European Union.

Although Romania was not among the first three Central European countries invited at the June 1997 Madrid Summit² to join NATO, then US President Bill Clinton visited Romania one month later and launched the idea of a bilateral Strategic Partnership between the United States and Romania. From that moment, Washington-Bucharest relations have continuously increased, especially on the issue of security. In 2001 and 2003, Bucharest decided to send troops to Afghanistan and Iraq, to support NATO/international coalition forces led by the US. Romania and another six countries ${ }^{3}$ from the former socialist bloc were invited to prepare for accession to the North Atlantic Alliance at the Prague Summit of November 2002, eventually achieving membership on 29 March 2004.

Since the Ukrainian crisis started, as Magnus Petersson remarked, "economic and political sanctions have been imposed on Russia by the West, and NATO has reinforced its military readiness in general, and in the Baltic States, Poland, and Romania in particular" (Petersson 2015: 115). It is not by mistake that Bulgaria or Turkey is omission from the above mentioned 'priority list'. While Bulgaria was rather soft and doubtful in its discourse related to international sanctions against Russia, and did not ask for more NATO presence on its territory, Turkey was not treated as part of the Eastern Flank in the way that the post-communist countries were treated at the Wales and Warsaw NATO summits, in 2014 and 2016. There were also no special mentions for Hungary and Slovakia, two countries on NATO's eastern frontier, having fairly good relations with Russia.

In February 2017, a surprising poll conducted by WIN/Gallup International found "Bulgaria, Greece, Slovenia and Turkey picking Russia as a defence

2 The first wave of NATO Eastern enlargement included Poland, Hungary and the Czech Republic.

3 Bulgaria, Slovakia, Slovenia, Lithuania, Latvia and Estonia. 
partner if a threat emerged" (Novinite 2017), while the vast majority of NATO member states prefer the United States as their main partner in terms of national defence. The same survey confirmed that Bulgaria and Greece see their biggest security threat coming from Turkey, an ally within NATO.

The observation that four NATO member states, that is a large part of the region of Southeast Europe, 'rely' more on Russia than on the US for their defence, is obviously surprising and somehow illogical for the Alliance. However, this is explained by the finding that two of them, Bulgaria and Greece, consider another NATO member state, that is, neighbouring Turkey, as the biggest threat to their national security. The decline of traditional US based collective security consensus in the North Atlantic area, a decline which peaks in the region of Southeast Europe but is also manifest in the new Franco-German project of the European Defence, could be relevant for the perspectives of the changing political discourses on NATO in Europe.

Between the presidential and the parliamentary elections in Bulgaria, in February 2017, then former Prime Minister Boyko Borissov made a 'title of glory' in resisting Bulgaria's participation in a projected NATO Black Sea flotilla with Romania and Turkey, pretending that he was thus defending the fundamental interests of Bulgaria Criticising the new President Radev for the implementation of older agreements with NATO, actually decided during his term as head of the government until 2016, Borissov remarked in an electoral speech:

\begin{abstract}
"Now we are being included, we had air policing, now we have a flotilla, foreign ships... Now we are being put in a very delicate situation, he said, recalling his stated dream of 'seeing only sailboats, yachts and a gas pipeline in the Black Sea'. In response, the Bulgarian Socialist Party leader Kornelyia Ninova accused Borissov of changing positions. 'Yesterday's hawk Borissov is trying to turn into a sparrow today, but it is not working', she said" (Cheresheva 2017).
\end{abstract}

But the maneuver actually worked, as Boyko Borissov and his centre-right wing party GERB won the parliamentary election on 26 March 2017, with 32 percent of the vote, and Borissov returned as Prime Minister of Bulgaria, 
leading a coalition government with the nationalist party, United Patriots. Now the confusion of strategic thinking is even deeper in Bulgarian politics, with a socialist "pro-Russian" president in favour of lifting sanctions against Russia while formally being a NATO supporter, and with a centre-right wing prime minister who is considered to capitalize politically from opposing to NATO naval cooperation in the Black Sea.

Political and military support of the US administration and the idea of NATO Black Sea naval cooperation (flotilla), regardless of whether it originated in Romania or not, was suggested in February 2016 by the US Ambassador to Romania, in a public debate organized by the think tank Citadel at Babes-Bolyai University Cluj-Napoca:

"We will continue to rotate U.S. naval vessels into the Black Sea, but it will not be on a level that can rival Russia's naval presence in the Black Sea. While we will continue to provide credible deterrence in other realms to our three NATO Black Sea Allies, it will be dependent on these three nations to work even closer together to bolster common security, especially in the naval realm. There are many things these three states can and should be doing to improve NATO military capabilities in and around the Black Sea. The first step would be to meet often at high and working levels to discuss the security picture, their capabilities, and how they can work together. The U.S. is happy to play a supporting role in this" (Hans Klemm 2017: 65).

It is not a surprise to observe that the US government chose to make clear this intention to strengthen military cooperation in the Black Sea region only in Romania. Launching this ambitious strategic idea in a very pro-NATO country and waiting for echoes in the region was like testing the three Black Sea allies. Bucharest has been, for the last decade, the most fervent supporter of the North-Atlantic Alliance in South East Europe as well as in the Black Sea region, and the project was very well received not only by Romanian political and military elites, but also by civil society and academia.

The changing discourses on NATO in Bulgaria, combined with massive electoral speculations on this topic, reveal that popular support for the North-Atlantic Alliance and its strategic policies is more or less weakening 
in this country, and different leaders think they can gain some political capital from this change. The fact that Boyko Borissov opposed in the summer of 2016, just before the Warsaw NATO Summit, the idea of a Black Sea flotilla with the participation of Turkey and Romania, and with the support of the United States, was a real political surprise for Bucharest and maybe for other NATO capitals. The Romanian President Klaus Iohannis, who learned about the Bulgarian "veto" during an official visit to Sofia in June 2016, after having obtained the support of the outgoing President Rosen Plevniev, insisted that the "Black Sea initiative of naval cooperation is a very good idea, intending to make compatible and to coordinate the actions of the three Black Sea allies" (lohannis quoted by Elena Mitrovici and Diac 2016), at least common training and military drills. As possible justification of this odd Bulgarian attitude, the traditional cold relationship between Bulgaria and Turkey could be invoked, but its negative reflection on NATO is not a good sign for the effectiveness of the Alliance in the south of the Eastern Flank.

\section{The West, NATO and Turkey}

While change and ambiguity seem the characteristics of the main Bulgarian political actors (the new president, the new government and opposition) in NATO related discourses, Turkey faces other types of problems. Specifically, Turkey faces domestic turbulence and declining relations with Western democracies. Political cleansing after the attempted coup of July 2016, the abuses of the Erdoğan regime against mass-media/independent journalists, civil society, academia and also against the independence of the judiciary, as well as the controversial referendum for switching to an autocratic presidential regime in April 2017, questioned even Turkey's candidacy to the European Union and membership to NATO. The EU Commissioner lohannes Hahn concluded that "Turkey's EU dream is over, for now" (Emmot 2017).

Not only is Turkey's European integration called into question, but also Ankara's membership to the North Atlantic Alliance is now seen in a different light. Although the democratic, rule of law and human rights 
criteria do not have the same crucial role in NATO as in the European Union, recent political developments in Turkey overshadow even the key geostrategic position of this country, between the West and the Middle East. The odd rapprochement between Turkey, Russia and Iran, and the numerous meetings between presidents Erdoğan and Putin after 2016 , amidst the deterioration of both countries' relations with the West, raised suspicions of how much NATO could rely on Turkey during a crisis in international relations.

The most radical opinions say "it's time to kick Erdoğan's Turkey out of NATO", as Stanley Weiss wrote for Huffington Post in 2016. As for the argument, Weiss appreciates that Turkey is:

"Defiantly supporting the Islamic State and its war against the West [...] Erdogan, who is Islamist to the core, who once famously declared that 'the mosques are our barracks, the domes our helmets, the minarets our bayonets, and the faithful our soldiers'seems to see himself as the Islamic leader of a post-Arab-Spring Muslim world. He has spent the past 13 years dismantling every part of Turkish society that made it secular and democratic, remodelling the country" (Weiss 2016).

Whether radical opinions are largely embraced or not, moderate critics in the United States and Europe would like to see Turkey more politically and militarily engaged in compliance with Western values and interests, according to the status of a NATO member state. In 2016, Turkey participated in only four out of the 18 major NATO drills, in spite of being the fourth largest military power of the Alliance. According to Bloomberg:

\footnotetext{
"The US and its top European allies tolerate this because a Turkish departure would, in effect, put the Black Sea and the Balkans officially in play as parts of the world where Russia and Turkey openly vie for influence. The West would also lose a key Middle Eastern foothold" (Bershidsky 2017).
}

Turkey's position itself differs substantially when it comes to the European Union and NATO. President Erdoğan became much more assertive in relation to the European Union in the past two years, even threatening a referendum for cancelling negotiations for joining the EU, while the topic 
of NATO membership is kept in silence. The most reasonable explanation for this different attitude is that Ankara realizes it has no chances of joining the European Union, but NATO membership could be useful for its security one day, in the turbulent region of the Middle East.

The cancelation of Turkey's participation to many NATO exercises could be explained by the worsening relations with some European allies, such as the Netherlands, France and Germany. Erdoğan even named some Western European governments as "Nazis", after the interdictions on Turkish officials attending electoral meetings with Turkish communities in these countries, for the constitution referendum of 16 April 2017. Things became even clearer with Angela Merkel's firm statement on Europe Day that Germany rules out any electoral process and vote on German soil in a potential Turkish referendum for reintroducing the death penalty in Turkey (Hurriyet Daily News 2017). Just a few days before the Hamburg G20 Summit of July 2017, the German government also announced that President Erdoğan will not be allowed to address the Turkish community living in Germany.

Criticism of Turkey's relations with NATO is not limited to Ankara's nonparticipation in the Alliance's exercises. The assessments go deeper in the hard-core of the new Turkish political ethos. In an analysis for Foreign Policy, John Hannah concludes that:

"Erdogan is a failure. But he is also a growing threat to U.S. interests. His policies are certainly endangering the well-being and stability of Turkey, a vital member of NATO. But they are also fanning the flames of extremism and terrorism beyond Turkey's borders - in Syria and the Middle East for sure, but increasingly in Europe as well. The country that is supposed to be a reliable bulwark for security and stability on NATO's southern flank is fast becoming a major source of risk to both the alliance's democratic values and, and more importantly, its interests" (Hannah 2016).

For his part, President Erdoğan does not seem to be very happy with the current NATO programmes and would like to see the Alliance more involved in "fighting global terrorism". To some extent, it makes sense that any of NATO's member states would like to attract more of the Alliance's 
interest in their regions and to their specific problems, but any "out of area operation" should be evaluated and prepared with much caution, especially in a sensitive region such as the Middle East. The Turkish leader considers that:

\begin{abstract}
"As we have seen from the terrorist attacks first in Istanbul and then in Iraq and Saudi Arabia, international security is becoming more fragile [...] The concept of a security threat is undergoing a serious change. In this process, NATO needs to be more active and has to update itself against the new security threats. As a NATO country, we want fellow members not to forget about Turkey" (Pamuk 2016).
\end{abstract}

The implication of NATO in Middle East conflicts is not something that western allies are ready to decide, despite Turkey's insistence. Moreover, Germany announced in June 2017 the withdrawal of its troops from the strategic NATO base in Incirlik, in the south of Turkey, close to the Syrian border. The decision of the government in Berlin was largely understood as a new and clear form of distancing from the Erdoğan regime.

\title{
Conclusions: growing differences in political discourses on NATO
}

Starting from the question of stability or change in NATO's discursive representations in the Black Sea region, in the context of very dynamic contemporary international politics, the article reviewed the main recent approaches with regard to the political and military North Atlantic Alliance, in Romanian, Bulgarian and Turkish politics.

We do not claim that this article can reveal the whole picture/truth of politics and society. Looking exclusively at the tip of the iceberg could probably represent a limitation of this scientific demarche. For instance, we do not have enough or equal information from what the civil societies believe about NATO in the region. Whether independent authors and experts' voices are stronger and can be easily identified in Romania, 
there are only a few signals from the Turkish civil society so that Turkey is identified here with Erdoğan, which is probably not reflecting the whole truth for such a big country. The WIN/Gallup International poll of February 2017 gives interesting and surprising indicators for Southeast Europe and further research would be probably meaningful. However, elected political leaders have democratic legitimacy to speak on behalf of their countries and we may assume that, in such regimes, a majority of the citizens agree with their presidents or prime ministers. The analysis clearly reveals that the "turbulences" in global and European politics in the past years prompted changes of attitude in some NATO member states in the region. While Romania remained steady in its pro-Atlanticist foreign policy and a very close ally of the United States, Bulgaria and Turkey suffered smaller or bigger changes in their political discourses on NATO.

Nowadays the three NATO member states in the Black Sea region have different political attitudes with regards to the North-Atlantic Alliance. It is not only the fact that there are different political attitudes in relation to NATO in Bucharest, Sofia and Ankara, but these differences are actually growing. The divergent trend is mainly based on quite different domestic political and cultural conditions. This aspect is to some extent concerning, since the three allies represent the geopolitical "gates" of NATO to the sensitive and unstable region of the Black Sea. Romania, Bulgaria and Turkey are also parts of the Montreux Convention of 1936, ${ }^{4}$ regulating the regime of the straits between the Black Sea and the Mediterranean Sea and the transit of the warships on the Black Sea.

Among the three allies of the Black Sea region, Romania is by far the most NATO and US-politically oriented country in Southeast Europe. Based on the Strategic Partnership with the United States established in 1997, in the past 20 years Romania has developed several agreements with the US in the field of security, including two American military bases and components of the US anti-missile shield. The visit of Romanian President Klaus lohannis to Washington, in June 2017, fully reconfirmed the importance of bilateral relations. President lohannis was the fourth EU leader to visit the White House after the inauguration of the Trump

4 A multilateral Treaty signed on 20 July 1936, in Montreux (Switzerland), originally by Australia, Bulgaria, Greece, France, Japan, Romania, Turkey, Yugoslavia, the UK, the USSR (in alphabetical order) in which Turkey received internationally recognized control over the Straits of Bosporus and Dardanelles. The Treaty was then submitted to the League of Nations. The Montreux Convention is still in force, with some minor amendments. 
administration and the first president or prime minister from Central and Eastern Europe to be received by the US President. As Iohannis declared in Washington, "my country is the most pro-American out of the EU. Over 70 percent of Romanians have a positive sentiment towards the US [...] Romania supports a tight cooperation between NATO and the EU. There is no alternative to the strongest and most successful alliance in the history" (lohannis quoted by Posirca 2017).

The southern neighbour, Bulgaria, balances between the West and Russia. With a socialist president advocating for lifting Russian sanctions and a right wing prime minister opposing the idea of the NATO Black Sea flotilla, Bulgaria would actually like to be in "two boats", with western political guaranties, but also with some economic benefits from Russia. Culturally, Bulgarians feel closer to Russia and, as polls revealed, rely more on Russia for their national security than on any other great power, which is absolutely surprising for a NATO member state.

Turkey is undergoing a complex and confusing political and societal transformation towards a post-Kemalist model of Islamic state. After the failed coup of July 2016, Turkey's relations with the United States have seriously deteriorated, based on Ankara's allegations with regards to the implication of Turkish American resident Fetulah Gullen in the coup attempt. Not only did relations with the US worsen, but so did relations with Germany, the Netherlands and other Western European allies, making Turkey a rather politically isolated country within NATO.

This article shows that the traditional heterogeneity of the Black Sea region is reflected today even between the three NATO member states, influencing their commitment to the Alliance's purposes and strategies. From the north/Romania to the south/Turkey of the Black Sea region, with some ambiguity in-between/Bulgaria, the previously pro-West attitude is visibly decreasing. Romania, Bulgaria and Turkey fully represent the three different nuances depicted in this paper: stability, ambiguity and change. In comparison with the north of NATO's Eastern Flank, which seems more united in its strategic options and a more coherent region, articulated between Poland and the Baltic States, the south of the Eastern Flank looks weaker, heterogeneous and increasingly divergent. This reality should be treated seriously by NATO strategists and decision-makers. 


\section{( Bibliography}

Ascherson, N., 2007. Black Sea: Coasts and Conquests: From Pericles to Putin: The Birthplace of Civilisation and Barbarism. London: Vintage.

Bershidsky, L., 2017. Turkey's Troubled NATO Status. Bloomberg View, 14 March [online]. Available at: https://www.bloomberg.com/view/ articles/2017-03-14/turkey-s-nato-status-grows-more-troubled (Accessed May 2017).

Buzan, B., 1991. People, States and Fear: An Agenda for International Security Studies in the Post-Cold War Era. Second edition, Hertfordshire: Harvester Wheatsheaf.

Cheresheva, M., 2017. NATO Black Sea Plans Cause Dissent in Bulgaria. BalkanInsight, 22 February [online]. Available at: http://www. balkaninsight.com/en/article/nato-black-sea-region-plans-causeroar-in-bulgaria-02-22-2017 (Accessed April 2017).

Emmott, R., 2016. Exclusive: Turkey purges NATO military envoys after failed coup. Reuters, 12 October [online]. Available at: http://www. reuters.com/article/us-turkey-nato-exclusive-idUSKCN12C16Q (Accessed February 2017).

Emmott, R., 2017. Turkey's EU dream is over, for now, top official says. Reuters, 2 May [online]. Available at: http://www.reuters.com/ article/Us-turkey-eu-idUSKBN17YOUO (Accessed May 2017).

Erlanger, S. and Meyers, S., 2008. NATO Allies Oppose Bush on Georgia and Ukraine. The New York Times, 3 April [online]. Available at: http://www.nytimes.com/2008/04/03/world/europe/03nato.html (Accessed February 2017).

Euronews, 2016. Pro-Russia candidate wins Bulgarian presidential runoff. Euronews, 13 November [online]. Available at: http://www. euronews.com/2016/11/13/bulgarian-pm-borisov-to-resign-afterpresidential-vote-defeat (Accessed February 2017).

Franc-loan, V., 2000. Din lucrările Comisiei de la Snagov - martie-iunie 1995. Bucharest: Centre for Information and Economic Documentation. 
Hannah, J., 2016. How Do You Solve a Problem Like Erdogan?. Foreign Policy, 15 June [online]. Available at: http://foreignpolicy. com/2016/06/15/how-do-you-solve-a-problem-like-erdogan/ (Accessed May 2017).

Hurriyet Daily News, 2017. Merkel rules out Turkish vote in Germany on death penalty. Hurriyet Daily News, 9 May [online]. Available at: http://www.hurriyetdailynews.com/merkel-rules-out-turkish-vote-ingermany-on-death-penalty-.aspx?pagelD $=238 \&$ nID $=112902 \& \mathrm{New}$ sCatID=351 (Accessed May 2017).

Kaplan, D. R., 2014. The Revenge of Geography: What the Map Tells Us About Coming Conflicts and the Battle Against Fate. Bucharest: Litera.

King, C., 2004. The Black Sea: A History. New York: Oxford University Press.

Klemm, H., 2017. On Naval Cooperation of the NATO Black Sea Allies. In: Valentin, N. ed. The Crisis of the European Union and the Global Order in the Trump Era. Bucharest: Trei Publishing House. pp. 60-66.

Luciani, G., 1989. The economic content of security. Journal of Public Policy, 8(2): 151-173.

Mayer, S., ed. 2014. NATO's Post-Cold War Politics. The Changing Provisions of Security. Basingstoke and New York: Palgrave Macmillan.

Ministry of Defence of the Republic of Bulgaria, 2017. Bulgaria in NATO. [online] Available at: https://www.mod.bg/en/cooperation_NATO. html (Accessed February 2017).

Ministry of Foreign Affairs of Romania, 2017. Romania-NATO. [online] Available at: https://www.mae.ro/en/node/2066?.page=2 (Accessed February 2017).

Ministry of Foreign Affairs of the Republic of Turkey, 2017. Turkey's relations with NATO. [online] Available at: http://www.mfa.gov.tr/nato. en.mfa (Accessed March 2017).

Mitrovici, E. and Diac, M., 2016. The Bulgarian Prime Minister opposes to the Black Sea flotilla. President lohannis insists it is a good idea. România Liberă, 16 June [online]. Available at: http://www.romanialibera.ro/ actualitate/international/premierul-borisov-se-opune-flotei-natoin-marea-neagra-419975 (Accessed May 2017). 
National Defence College of Canada, 1989. Course documents. Kingston: National Defence College Publishing.

Novinite, 2017. Bulgaria, Other 3 NATO States Picked Russia to Defend Them If Threatened. Novinite, 19 February [online]. Available at: http://www.novinite.com/articles/178963/Bulgaria\%2C+3+Other +NATO+States+\%27Picked+Russia+to+Defend+Them+if+Threaten ed\%27 (Accessed April 2017).

Pamuk H., 2016. Turkey's Erdogan call on NATO to do more on fighting militant attacks. Reuters, 8 July [online]. Available at: http://www. reuters.com/article/Us-nato-summit-erdogan-idUSKCNOZOOKR (Accessed May 2017).

Petersson, M., 2015. The US NATO Debate: From Libya to Ukraine. New York: Bloomsbury Academic.

Posirca, O., 2017. President lohannis: Romania has the biggest proAmerican sentiment in the EU. Business Review, 8 June [online]. Available at: http://www.business-review.eu/featured/presidentiohannis-romania-has-the-biggest-pro-american-sentiment-in-theeu-139510 (Accessed June 2017).

Schmidt, G., 2014. From London to Brussels: Emergence and Development of a Politico-Administrative System. In: Mayer, S. ed. NATO's PostCold War Politics. New York: Palgrave Macmillan. pp. 31-49.

Thies, W., 2009. Why NATO Endures. Cambridge: Cambridge University Press.

Trager, F. N. and Simonie, F., 1973. An Introduction to the Study of National Security. In: Trager, F. N. and Kronenberg, P. S. National Security and American Society: Theory, Process and Policy. Kansas: University Press of Kansas. pp. 33-51.

Tsygankov, A., 2009. Russophobia: Anti-Russian Lobby and American Foreign Policy. New York: Palgrave Macmillan.

Weiss S. 2016., It's Time to Kick Erdoğan's Turkey Out of NATO. Huffington Post, [online]. Available at: http://www.huffingtonpost.com/stanley-weiss/ its-time-to-kick-erdogans_b_9300670.html (Accessed May 2017). 
Valentin Naumescu (valentin.naumescu@ubbcluj.ro) is Associate Professor of Foreign Policy and Diplomacy and Comparative Politics at the Faculty of European Studies, Babeş-Bolyai University Cluj-Napoca, coordinating the master program in International Relations, Foreign Policy and Crises Management. $\mathrm{He}$ is an independent expert of the European Commission and the founder of the think tank Citadel, specialized in international politics. Dr. Naumescu also has diplomatic experience, serving as Consul General of Romania in Toronto (2008-2012) and Secretary of State in the Ministry of Foreign Affairs (2005-2007), with the diplomatic rank of Minister Counsellor. His most recent book is The Crisis of the European Union and the Global Order in the Trump Era (2017). 